\title{
Księgozbiór kanonickiej Biblioteki Bożego Ciała w XV i XVI w.
}

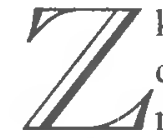

kanon kanoników regularnych oparty na regule św. Augustyna, łączący życie kontemplacyjne z pracą duszpasterską i naukową słynął z posiadania bibliotek i prowadzenia szkół. Szczegółowe przepisy poszczególnych domów zawsze zwracały uwagę na problem gromadzenia księgozbioru, najstarszym tego rodzaju dokumentem są „Antiquae consetudines canonicorum regularium" opata Gilduina (1113-1155) dla klasztoru św. Wiktora w Paryżu. Miały one wpływ na powstawanie przepisów w innych klasztorach korzystających z reguły św. Augustyna'. Dotyczy to również klasztoru kanoników regularnych laterańskich, osadzonych na Kazimierzu pod Krakowem przy kościele Bożego Ciała w 1405 roku²

Znaczenie książki w życiu kanoników regularnych obrazują zapisy wizytacji zakonnych i posiedzeń kapituł. „Lectio librorum” w 1685 r. kapituła generalna określiła jako pierwszy z pozachórowych obowiązków kanonika, obok przygotowywania kazań i prac ręcznych ${ }^{3}$. Wizytacja biskupa Jerzego Radziwiłła z końca XVI w. nakazywała sporządzanie podwójnego katalogu zbiorów biblioteki: dla bibliotekarza i prepozyta, a także odnotowywanie w rejestrze daty wypożyczenia i nazwiska pożyczającego. Zwracała też uwage na zwrot przetrzymywanych książek do biblioteki ${ }^{4}$.

Kanonicy przy kościele Bożego Ciała początkowo, jak to było zresztą powszechnie praktykowane, przechowywali kodeksy w zakrystii. Z biegiem czasu oddzielenie librarii stało się konieczne ze względu na przyrost księgozbioru. Oczywiście w zakrystii musiały pozostać książki potrzebne do sprawowania liturgii. Właściwa biblioteka znalazła pomieszczenie w budynkach klasztornych. Już w 1407 r., dwa lata po oficjalnej erekcji klasztoru Bożego Ciała, Piotr Wysz jako prywatny benefaktor darował klasztorowi leżącą po sąsiedzku posiadłość - dom z ogrodem, przeznaczając ją na infirmerię i bibliotekę. Darowiznę tę potwierdził Władysław Jagiełło aktem z $1426 r^{5}$ Oczywiście można snuć przypuszczenia, że skoro kanonicy nie Z Badań Nad Polskimi Księgozbioram Historycznymi t. 21, Warszawa 2003. 
mogli jeszcze w tym czasie posiadać zbyt wielu książek, wspomniana libraria miała być także skryptorium. ${ }^{6}$ Co gwarantowało wzrost księgozbioru? Książki do klasztoru BC spływały naturalnymi drogami:

1. Darowizn i legatów testamentowych dobroczyńców klasztoru

2. Darowizn miejscowych zakonników

3. Zakupu

4. Produkcji własnego skryptorium

Przykładem typowym niezbędnego w każdej bibliotece zbioru liturgicznego kościoła parafialnego są księgi BC na Kazimierzu, wymienione w spisie 1399 r.: czyli kilka mszałów, 4 antyfonarze, 3 psałterze, 2 części czytań z żywotów świętych i księga do nabożeństw nocnych. ${ }^{7}$ Odnotowuje go E. Potkowski, a zapewne też ta wiadomość stała się podstawą omyłkowo podanej przez M. Gębarowicza liczby tomów antyfonarza zachowanego w bibliotece $\mathrm{BC}{ }^{8}$

Klasztory kanonickie reprezentowały w późnym średniowieczu nurt zdecydowanie reformistyczny, zajmowała je praca dydaktyczno-kaznodziejska, realizowana w prowadzonych przez nich szkołach i parafiach. Zdecydowanie było to środowisko o sporych aspiracjach intelektualnych, zainteresowane humanizmem i różnymi naukami praktycznymi. Przywołać tu można bibliotekę klasztoru kraśnickiego kanoników regularnych, ściśle związanego z BC, w której znajdowały się głównie teksty fachowe kleru parafialnego, a wiec z zakresu teologii praktycznej i kaznodziejstwa. ${ }^{9}$

Ośrodkami wyjątkowymi jeśli idzie o kulturę książki były prowincjonalne miejscowości, w których działały zgromadzenia kanonickie. Największy księgozbiór posiadał klasztor kanoników regularnych w Żaganiu. ${ }^{10} \mathrm{Przy}-$ wołać też można bibliotekę odrębnej kongregacji kanonickiej, którą gromadził też klasztor w Czerwińsku, aktywny ośrodek kulturalny na Mazowszu, utrzymujący kontakty ze środowiskiem leodyjskim. "

Największe biblioteki klasztorne późnego średniowiecza posiadały od 1000 do 2000 tomów, mniejsze około kilkudziesięciu. Zrozumiałe jest, że podstawę tych zbiorów stanowiła literatura ściśle teologiczna, lub teologii podporządkowana. Trudno jednak dokonać ścisłego podziału na grupy treściowe gdyż zacierają się granice między poszczególnymi dyscyplinami, średniowieczna „doctrina sacra” łączyła w sobie dogmatykę z teologią moralną. Jej wyrazistym przykładem będą tu zarówno Sentencje Piotra Lombarda jak i Suma teologiczna Tomasza z Akwinu. Osobno idzie sama historia Kościoła i prawo kanoniczne (od XII w.). Trudności logicznego rozgraniczenia grup treściowych towarzyszy jeszcze problem fizycznego funkcjonowa- 
nia rękopisu, a także i inkunabułu, w postaci klocka. Inwentarze klasztorne zachowuja jednak pewien podstawowy schemat:

* Biblia i jej komentarze

* Pisma Ojców Kościoła

* Literatura teologiczna

* Kazania

* Prawo

* Literatura szkolna

Biblioteka BC posiada dzisiaj bardzo małą kolekcję rękopisów, najwięcej szkód poczynił tu zapewne wiek XVII. Rękopisy filozoficzne i teologiczne zinwentaryzowała Zofia Włodek ${ }^{12}$, liturgicznymi interesowała się H. Pieńkowska. ${ }^{13}$ Opisany przezZ. Włodek zespół 14 woluminów rękopisów obejmuje teksty pisane w XV w., są to kodeksy papierowe, bez szczególnego zdobienia iluminatorskiego. Nie ujęła jednak wszystkich, odnaleziono jeszcze dwa samodzielne rękopisy ${ }^{14}$ i 4 oprawne razem $z$ inkunabułami. ${ }^{15}$

Spośród całego zbioru wyróżniają się: polemiczne traktaty antyheretyckie Quaestio de communione sub utraque specie i Quaestio de indulgentiis Franciszka Krzysowicza z Brzegu, profesora Akademii Krakowskiej ${ }^{16}$, Postilla Jana Szczekną z Pragi, cystersa, kapelana królowej Jadwigi i również profesora $\mathrm{AK}^{17}$, Expositio super Psalterium Mikołaja z Pyzdr ${ }^{18}$, popularne zbiory kazań Jakuba de Voragine ${ }^{19}$ i Piotra de Palude ${ }^{20}$, Sacramentale Mikołaja z Błonia, napisany na zlecenie biskupa poznańskiego ok. 1430 r. podręcznik kleru parafialnego, dotyczący całości problemów doktrynalno-kultowych ${ }^{21}$ oraz słynna Postilla studentium austriackiego reformatora i kaznodziei doby przedhusyckiej, działającego w Czechach, Konrada Waldhause$\mathrm{na}^{22}$. Posiadali też kanonicy syntetyczny podręcznik teologii biblijno-dialektycznej Sententiae Piotra Lombarda ${ }^{23}$, był on bardzo rozpowszechniony w Polsce i zapewne od XIV w. wchodził do programu nauczania w krakowskiej szkole katedralnej ${ }^{24}$.

Zachowane fragmenty wskazują więc wyraźnie na zainteresowanie literaturą fachową, wykorzystywaną w pracy duszpasterskiej ${ }^{25}$, ale też dbałość o dekoracyjną książkę liturgiczną. Podobnie zresztą kształtowały się pod względem treściowym inne kanonickie biblioteki, np. Żagań. Warto prócz tego zanotować, że kazania w parafialnym kościele kanoników regularnych głoszono po polsku i po niemiecku ${ }^{27}$.

Zawartości tematycznej późnośredniowiecznych księgozbiorów polskich nie można ująć liczbowo (jak rękopisów). Zależała ona od potrzeb społecznych, widać wyraźnie, że jako pierwsze drukami będzie piśmiennic- 
two religijne, choć jego charakter sakralno-kultowy rozbudowany zostanie o narzędzia działalności duszpasterskiej i teksty łączone z różnymi sporami doktrynalnymi.

Jeśli chodzi o zbiory BBC zachowały się do dzisiaj trzy katalogi ujmujące książkę stara, pierwszy pochodzi z 1741 roku $^{28}$, drugi z $1811^{29}$ (pojawiają się tutaj bardzo nieliczne książki z XIX w.), co prawda Archiwum BC przechowuje jeszcze katalog datowany na 1905 r., ale jest on jedynie wierną kopią wspomnianego spisu z roku 1811.

Katalog z 1741 r., spisany przez Stanisława Piechnikiewicza, obejmuje 2711 dzieł (brak ilości woluminów), z kolei w 1811 r. brano pod uwagę woluminy właśnie, ogólna ich liczba wynosi 5190. Wykaz uzupełnia też osobny wykaz 54 rękopisów ${ }^{30}$, ale niestety zdarzają się też omyłkowe wpisy w samym katalogu (dotyczy to zarówno opisu fizycznego, jak i mylnego, niekonsekwentnego przydziału do grup treściowych). Dzisiaj liczbę wszystkich starodruków zgromadzonych w BBC można podać jedynie szacunkowo, jest ich ok. 4000 . Z tej sumy prawie 250 dzieł to inkunabuły, z XVI wieku pochodzi zaś ok. 1000 woluminów (liczba tytułów może być podana dopiero po analizie klocków i defektów). Suma ta jest porównywalna $\mathrm{z}$ ilością dzieł wymienionych przez katalog z 1811 r., ponieważ w wykazie często zdarzają się braki dotyczące miejsca i roku wydania (spisujący miał kłopoty zwłaszcza z inkunabułami) należy je uwzględnić i przyjąć, że liczba druków XV-XVI w. wynosi 1200 woluminów.

* bez daty lub mylna $=478$

$* \mathrm{XV} \mathrm{w}=26$

$*$ XVI w. $=684$

Katalog dzieli księgozbiór na działy: 1. Libri Theologici 2. Opera SS. Patrum 3. Libri Biblici 4. Libri Ascetici (expositores) 5. Libri Iuridici 6. Conciones in 1. Latina 7. Conciones in 1. Pol. 8. Philosophici 9. Rethorici 10. Historici 11. Miscelanea

Najwięcej książek pochodzi z oficyn niemieckich: Kolonii (144), Frankfurtu (18), Lipska (12), ogółem 193. W dalszej kolejności trzeba wymienić Francję: Lyon (91), Paryż (23), ogółem 114, Włochy z Wenecją 79, Niderlandy z Antwerpią 54, Szwajcarię z Bazyleą 53 i oczywiście Polskę z Krakowem (25) 29.

Znane są bliżej okoliczności powstawania katalogu z 1811 r. Za czasów Księstwa Warszawskiego powstał bowiem plan ministra spraw wewnętrznych Jana Łuszczewskiego i ministra sprawiedliwości Feliksa Łubieńskiego komasacji krajowych zbiorów bibliotecznych, na wzór powstałego 
w 1808 r. archiwum krajowego. Książki gromadzono w Warszawie w pałacu Biskupów Krakowskich (przy Sądzie Apelacyjnym na ul. Miodowej 496). Opiekę nad 20-tysięcznym w 1812 r. zbiorem objął bibliograf Mateusz Kozłowski. Z chwilą otwarcia w 1817 r. Uniwersytetu księgozbiór przeniesiono do Pałacu Kazimierzowskiego, a z czasem opiekę nad nim przejął Samuel Bogumił Linde. ${ }^{31}$

Zakony otrzymały polecenie nadesłania swoich katalogów. W 1810 r. urzędy administracyjne Księstwa otrzymały polecenie aby zbadać stan bibliotek klasztornych i zamknąć nieuporządkowane. Do powołanej krakowskiej komisji rewizyjnej wyznaczono hr. Stadnickiego, radcę administracyjnego oraz ks. Jerzego Mieroszewskiego, dziekana kolegiaty Wszystkich Świętych. Zwizytowali oni 13 krakowskich księgozbiorów. ${ }^{32}$

Biblioteką kanoników opiekował się wtedy Frygidian Bogdziński, zbiór porządkował bibliotekarz Michał Starowicz, planowano spisanie katalogu. Biblioteki więc nie zamknięto, a opracowany katalog znamy pod datą r. $1811^{33}$.

Prawie 250 druków pochodzących z XV w. to zasób spory, niektóre z nich to druki bardzo rzadkie (11 tytułów znanych w Polsce tylko na podstawie egzemplarza BBC). Trzeba zwrócić uwagę na XV-wieczne polonika, zwracają tu zwłaszcza uwagę dwa tytuły pochodzące z pierwszej tłoczni na ziemiach polskich. Początki drukarstwa w Polsce to lata 1473/74, związane są one z osobą Kaspra Straube z Bawarii, z jego krakowskiego warsztatu wyszły 4 druki, 2 spośród nich posiada BBC: zbiór traktatów prawniczych Opus restitutionum usuarum et excomunicationum franciszkanina Franciszka de Platea (2 egzemplarze) z 1475 r. i Opuscula św. Augustyna [ca 1476], zawierające 14 różnych utworów i najstarsze z XV-wiecznych edycji.

Generalnie produkcja drukarska tego czasu pochodzi głównie $\mathrm{z}$ dwu środowisk: niemieckiego i włoskiego. Niemcy z takimi ośrodkami jak: Kolonia (H. Quentell), Lipsk (C. Kacholofen), Strasburg, (G. Husner), Norymberga (A. Koberger) byli dostawcami Biblii, ksiąg liturgicznych, teologicznych w duchu scholastycznym, a także literatury użytkowej.

Ostoją tradycyjnej filozofii i teologii była właśnie Kolonia, scholastykę konserwatywnego uniwersytetu reprezentowali tu: Lambertus de Monte i Gerardus de Harderwyck, a przede wszystkim Jan Versor.

Z Lipskiem utrzymywano kontakty handlowe i one przyczyniały się do tego, że napływały do nas stąd podręczniki szkolne, dewocjonalia, książki astrologiczne. Strasburg dostarczał dzieł z zakresu prawa kanonicznego i rzymskiego, edycji Ojców Kościoła, ksiąg liturgicznych, ale też humani- 
stów. Od Kobergera z Norymbergii pochodzą encyklopedie, słowniki, biblie, druki prawne.

Włochy, z centralnym ośrodkiem Wenecją (O. Scotus, B. Locatellus) produkowały również literaturę scholastyczną, ale głównie druki laickie - kodeksy i traktaty prawnicze, dzieła humanistyczne, medyczne, astrologiczne, matematyczne.

Spośród XV-wiecznych wydań Biblii BBC posiada edycję wenecką z 1483 r., dwa wydania bazylejskie z 1487, druk A. Kobergera z 1487 Biblia, cum postillis Nicolai de Lyra. Warto odnotować też dziełko Mikołaja de Hanapis Biblia pauperum, wydane ok. 1498 r. Z komentarzy biblijnych pojawia się oczywiście wspomniany już Mikołaj de Lyra (Repertorium in Postillam... z 1494, druk Kobergera), Jan Beets (Commentum super decem praeceptis decalogi z 1486) Dalej Moralia, seu Expositio in lob Grzegorza I, wydane w Bazylei w 1496 r., De morali lepra [Basel, non post 1475] Jana Nidera. Z poczytnych utworów Jana Nidera mamy też w BBC Manuale confessorum [Basel, ca 1475] i Sermones de tempore et de sanctis cum quadragesimali wydrukowane w Ulm przez J. Zainera przed $1480 \mathrm{r}$.

Znajdziemy też się w BBC drukowane edycje popularnych dzieł Mikołaja z Błonia De sacramentis. Strasburg 1487, 1490, 1496 r., Sermones de tempore et de sanctis. Strasburg 1494, 1495 r. Naturalne dla kanoników regularnych było kompletowanie dzieł św. Augustyna, zachowały się więc w zbiorach: Enchiridion de fide, spe et caritate [Strasburg 1473], Opuscula -wspomiane już krakowskie [ca 1476], weneckie o innej zawartości z 1484, strasburskie z 1491, i jeszcze Explanatio Psalmorum, wydane w Bazylei przez Amerbacha. Znalazł się również w zbiorach Pseudo-Augustinus Sermones ad heremitas $\mathrm{z}$ ok. 1493/94 r.

Z ojców Kościoła znajdują się w BBC Opera św. Ambrożego (Basel, 1492), św. Bonawentury Opuscula. Strasburg 1489, 1495, św. Hieronima Aureola ex floribus s. Hieronymi contexta, ca 1472, Commentaria in Bibliam 1497-1498.

Gromadzili również kanonicy regularni wydania Jana Turrekrematy: $Q u-$ estiones evangeliorum de tempore et de sanctis (dwa niemieckie wydania z 1478 r.). Nie zabrakło podstawowego dzieła Tomasza z Akwinu Summa theologica z 1484, a także w wydaniach strasburskich J. Mentelina sprzed 1463 roku (są to najstarsze druki zachowane w BBC).

Kaznodziejstwo jest w zbiorach kanonickich reprezentowane $m$. in. przez Roberta Caracciolusa (de Liteo): Sermones de adventu [1477/78], Sermones de laudibus sanctorum w edycji augsburskiej E. Ratdolta z 1489, a także 
z 1490, Sermones quadragesimales de poenitentia [1475, ca 1479], przez druki Pseudo-Piotra de Palude: Sermones quadragesimales Thesauri novi z 1485, 1491, Sermones Thesauri novi de tempore 1486, Sermones Thesauri novi de sanctis 1484, 1489. Gromadzono również pisma Jakuba do Voragine, jego Sermones de tempore et de sanctis z [1485] czy słynna Legenda aurea w wydaniu z r. 1476, 1483, 1486, znajdują się oczywiście w BBC. Jest w zbiorach kazimierskich kanoników Postilla, sive praedicabile de Evangeliis ae Epistolis wydrukowana 1484 r., i aż trzy edycje Sermones super Cantica Canticorum Bernarda Claravallensis (Pavia 1482, Strasburg 1497, Brescia 1500). Kazania poświęcone kultowi maryjnemu były bardzo popularne, kanonicy posiadali np. dziełko wydane przed 1488 r. Corona Beatae Mariaae Virginis.

Sporo w BBC dzieł św. Alberta Wielkiego, sq̨ to Enarrationes in Evangelium loannis [przed 1477], Mariale [ przed 1486], Physica 188/89, Sermones de tempore et de sanctis [1478/80] i Summa de creaturis z 1498/99.

Prawo prezentowane jest przez Decretum Gracjana, wydane w Bazylei przez B. Richela w 1476 r., a znane w Polsce już w 2 poł. XII wie$\mathrm{ku}^{34}$. Kanonicy posiadali też egzemplarz pierwszego zachowanego na ziemiach polskich wydania Liber sextus Decretalium papieża Bonifacego VIII z ok. 1470/72, ale też i późniejsze z drukarni A. Kobergera z 1486 r. Były też kiedyś w BBC polskie Constitutiones vel Syntagmata [1487], będące pierwszą kodyfikacją prawa świeckiego.

Dział filozoficzny nie mógł się obejść bez takiego autora jak: Arystoteles, i tak mamy w BBC De animalibus w thumaczeniu Teodora Gazy, wydane w Wenecji w 1498. Są też komentarze do dzieł Arystotelesa autorstwa Aegidusa Romanusa (Idzi Colonna, generał augustianów eremitów): In Aristotelis Analytica posteriora commentum z 1495, In Aristoteli De anima commentum z 1496/97, In Aristotelis De sophistici elenchi commentum 1496/97, wszystkie zostały wydrukowane w Wenecji. Podobnie jak Pseudo-Aegidus In Aristotelis Analytica priora commentum wydane na zlecenie A. Torresano.

Dzieła medyczne reprezentuje Opera medicinalia Jana Mesue, wydrukowana w Wenecji w 1497 r., posiadają również kanonicy popularny i zaczytywany wręcz podręcznik przyrodniczy Herbarius, łaciński ale z synonimami w języku niemieckim, z ręcznie kolorowanymi drzeworytami, wydany w Passau w 1486 r.

Typowe średniowieczne ujecie całości wiedzy ludzkiej prezentuje popularna encyklopedia Wincentego Bellovacenis: Speculum historiale [ca 1473], 
Seculum morale 1476, Speculum naturale [przed 1479], Speculum doctrnale [ca 1477], trzeba tu zaznaczyć, że Wincenty z Beauvais mylnie uchodzi za autora „Speculum morale”- czwartej części swojego dzieła „Speculum maius".

W kanonickiej bibliotece zachował się jedyny polski egzemplarz De proprietatibus rerum Bartłomieja Angieusa, wydany ok. 1470 r. Ciekawym drukiem jest też niewątpliwie De arte loquendi et tacendi Albertanusa Causidicusa Brixiensis, w BBC mamy jedno z wczesnych wydań tego popularnego dziełka z $1489 \mathrm{r}$.

XVI wiek to spore zmiany jeśli chodzi o książkę, dominuje już druk i ustala się schemat samej formy książki. Obok ojców Kościoła wysuwają się na czoło polemiści reformacyjni, przyrodnicy, autorzy klasyczni. Ważniejsze ośrodki druku są nadal skupione w Niemczech, Włoszech, duże znaczenie zdobywaj ą Niderlandy, Francja i miasta szwajcarskie. Przemieszczaniu się książki, i zagranicznej i polskiej służyły głównie kontakty handlowe, intelektualne, osobiste. Prościej o samą systematykę treściową produkcji XVI-wiecznej. Widać to już w samej konstrukcji katalogów bibliotecznych. Jeśli chodzi o BBC wyznacznikiem jest tu przyjęty układ omawianego już katalogu $\mathrm{z} 1811 \mathrm{r}$.

Z okazalszych druków odnotować należy Biblię świętq w thumaczeniu Jakuba Wujka z 1599 r., wspaniałe osiagnięcie oficyny Jana Januszowskiego. Jest to jedno ze znaczniejszych poloników XVI w., zwłaszcza, że w ogóle nie zachowało się ich w BBC wiele. $Z$ innych wydań Biblii mamy jeszcze wydanie z 1545 (Lugduni) i 1567 (Antwerpia). Efektem pracy Erazma $z$ Rotterdamu nad poprawnym tekstem Pisma św. było rewelacyjne na tamte czasy thumaczenie Nowego Testamentu z pomoca języka greckiego i łacińskiego z 1516 r., w BBC Novum Testamentum Graecae et Latinae zachowało się w edycjach z 1526 i 1559 r. Po tej pracy zajął się Erazm wydawaniem całego szeregu pism patrystycznych, i tak mamy kanonickich zbiorach: Divi Ambrosii commentari in omnes D. Pauli Epistulas z 1540 r., opracowane przez niego pisma Jana Chryzostoma, Atanazego i Cypriana. Z pełnych edycji dzieł ojców Kościoła pojawia się np. wydanie św. Augustyna z 1580 r. i św. Grzegorza 1518 r. Jest też Theologia Specultativa św. Tomasza z Akwinu z $1575 \mathrm{r}$.

Z poloników katalog odnotowuje też Psalterz Dawidów Walentego Wróbla, profesora teologii w Akademii Lubrańskiego, a potem Akademii Krakowskiej, wydany w Krakowie w 1543 r., a także Postyllę Jakuba Wujka z 1590. Z zachowanych odnaleziono druk Aleksego Rodeckiego Dialec- 
tica Ioannis Caesarii (bez miejsca i daty), a także jeszcze jedną pozycję Jana Januszowskiego Pymander Mercuri Trismegisti Hannibala Rosselinusa, wydaną w Krakowie w 1586 roku.

Wśród książek teologicznych odnajdujemy oczywiście Sententiarum textus Piotra Lombarda. Bazylea 1510, i kolejne edycje z 1552, 1578, 1559. Literaturę polemiczną reprezentują Opus adversus... Jana Fabera przeciw M. Lutrowi, w wydaniu lipskim z 1523 roku, Disputationes adversus hereticum J. G. Brettanusa, Enchiridion locorum communium adversus Lutherum Jana Eckiusa z 1536, również Ecka Homilianum adversus haereticum z 1563. Z polskich twórców literatury kontrowersyjnej mamy Andrzeja P. Nideckiego Libri $V$ de fundamentis Ecclesiae, wydane w Krakowie w 1525 r. (2 egzemplarze), Stanisława Sokołowskiego Ephitalamium Episcopi cum sponsa Ecclesia (Kraków 1580) i Varia opera (Kraków 1590). Literaturę polemiczną reprezentuje również $O$ bóstwie przedwiecznym syna Bożego jezuity Marcina Śmigleckiego (Wilno 1595). Zachowały się w BBC liczne prohibity, dzieła Marcina Lutra, Filipa Melanchtona, Jana Ferusa, Pawła Ebera ${ }^{35}$.

Liczne są dzieła kaznodziejskie, z polskich mamy Kazania o siedmiu sakramentach Piotra Skargi (Kraków 1600), tegoż Kazania na niedziele i święta calego roku (Kraków 1595), Kazania o upadku i naprawie rodzaju ludzkiego S. Karnkowskiego (Poznań 1597). Z łacińskich Stanisława Sokołowskiego Sermones do consecracione episcopi, wydane w Krakowie w 1580. Dalej: Sremones domenicales de tempore et de sanctis Gabriela Biela (1592), Homiliae de tempore et sanctis Jana Fabera (1541), odnotowujemy też takich autorów jak Beda Venerabilis, Petrus de Palude, Jacobus de Voragine, Lodovicus Granatensis (przedstawiciel teologii ascetyczno-mistycznej).

Są też w BBC dzieła Roberta Bellarmina, jezuickiego przedstawiciela teologii kontrowersyjnej, np. Disputationis de controversis christianae $f i$ dei (Kolonia 1559).

Do działu filozoficznego katalog z 1811 r. włącza $\mathrm{m}$. in.: różne wydania Arystotelesa, często w thumaczeniu Teodora z Gazy czy opracowaniu Aleksandra Ficcolominiego, i tak mamy np. Libri VIII de republica (Paryż 1548), Philosophonum omnium opera (bazylejskie wydanie Oporyna $\mathrm{z}$ 1548), Problematum duo de quadraginta sectiones Aristotelis (Lyon 1572), Decem libri ethicorum Aristotelis (Paryż 1539). Znajdujemy też Compendium philosophiae naturalis Franciszka Titelmana (Lyon 1574), kilka dzieł o tematyce medycznej, jak Thesaums pharmaticus medicamentorum omnium Kaspra Schwencka (Bazylea 1587), Nova medicinae methodas Jana Hassura 
(Hagenau 1533), Practica medicina Jana Hertmana (Frankfurt 1594), Medicinae Salernitana Jana Curio (1591), a także Mathematicae constructiones Ptolemeusza (1549), Libri Ill ed re medica Jana Mesue (1548), Cnservandae bonae valetudinis Jana Curio (1582), czy Institutionum anatomicarum A. Vesaliusa (1538) i Historiae naturalis Pliniusza w weneckiej edycji Pawła Manucjusza z 1559 roku.

Wśród retoryków odnajdziemy kilka wydań autorów klasycznych: $\mathrm{Cy}$ cerona, Terencjusza, Owidiusza, Wergiliusza, Cezara, ale też epistolograficzną pracę Piotra Bembusa, znanego humanisty i współpracownika Alda Manucjusza, a także sekretarza Leona X, Epistolarum Leones X(1547) oraz Liber de generibus dicendi Jakuba Górskiego (1559).

Prawo reprezentowane jest przez kolejne wydania Decretum Gracjana (Wenecja 1595), Institutionum Justyniana (1589), Concilii Tridentini canones et decreta (Antwerpia 1596), Institutiones iuris canonici Jana Pawła Lancellotusa (Rzym 1583), pojawiają się także uchwały synodów krajowych Synodus Diaecesianae Plocensis wydane przez Alberta Baranowskiego (Kraków 1598) i Constitutiones et decreta condita in Provinciali Synodo Gnesnensi Stanisława Karankowskiego (Praga 1590).

Spośród książek historycznych uwagę zwracają Sarmatiae Europae descriptio Aleksandra Gwagnina (Spira 1581), Chronica seu historiae Polonicae compendiosa descriptio Jana Herbuta (Bazylea 1553), Polonia sive de origine et rebus gestis Polonorum libri XXX Marcina Kromera (Kolonia 1589). Mamy tu też Euzebiusza Historia ecclesiastica (Kolonia 1570).

Z XVI-wiecznych wydań obcojęzycznych katalog odnotowuje 17 książek w języku włoskim, innych nie wymienia. Weryfikacja stanu obecnego rzeczywiście wykazuje obecność w BBC książki włoskiej, rzadziej w języku greckim i polskim.

Jeśli chodzi o wiek XVI trudno być pewnym wszystkich danych, ponieważ zawartość księgozbioru cały czas ulegała różnym zmianom, części książek nie uda się już odnaleźć, ale też odnajdywane sąinne, wcale przez katalog z 1811 r. nie ujmowane.

Straty w kanonickim księgozbiorze przyniósł również wiek XIX, wiążą się one z poszukiwaniem i gromadzeniem książek przez J. M. Ossolińskiego prowadzonych przy pomocy S. B. Lindego, ale nie tylko. Prawdopodobne jest też „przeglądanie” ich zbiorów przez kanonika katedralnego Kazimierza Ostrowskiego, słynnego bezpardonowego kolekcjonera, którego biblioteka liczyła ponad 6000 pozycji, a po jego śmierci w 1799 r. rozeszła się na licytacji ${ }^{36}$. 
Wydaje się, że jeszcze przed 1806 r. Ossoliński był u kanoników osobiście i zabrał XVII-wieczny pamiętnik rajcy kazimierskiego Marcina Golińskiego (obecnie Ossolineum syg. 186-188).

J. A. Kosiński pisze:

„Wybierał również tedy Linde książki u kanoników regularnych przy kościele Bożego Ciała na Kazimierzu, zwanych popularnie bożociołkami lub ciołkami, lecz nie mógł z nimi trafić do ugody. Liczył jednak na pomoc kanonika Trzebińskiego, zwłaszcza gdy od nich łupy się już moim sposobem zdarzyły niezmierne, jak przypominał o tym Ossolińskiemu. Rzeczywiście, w księgozbiorze wiedeńskim znajdowała się wyjątkowo liczna grupa książek tej proweniencji (32 polonika XVI i druk obcy z XVI w.), a między nimi inkunabut..."37

Jest to druk: Constitutiones vel syntagmata Regni Poloniae (Leipzig, Conr. Kachelofen, 1487 ${ }^{38}$, książka cenna jako pierwsza kodyfikacja prawa świeckiego (obecnie 11 egzemplarzy w Polsce). Nie powinien więc też dzisiaj dziwić brak polskich poloników XVI wieku w BBC w Krakowie.

Podana szkicowa charakterystyka księgozbioru nie podejmuje analizy proweniencji kanonickiego zbioru, praca nad opracowaniem księgozbioru trwa. Oczywiście już w tym momencie otoczenie kazimierskiego klasztoru rysuje się bardzo szeroko. Stosunkowo dużo zachowanych wpisów własnościowych pochodzi od miejscowych zakonników: Stanisława Manieckiego, Adama Inowłodzkiego, Jana Kazimierskiego, Pawła Łyczko, Stanisława Rogoźnego, Pawła Pukała, Błażeja Rosińskiego, Lukasza Nowaka i innych. Wiele książek otrzymywali od związanych z klasztorem osobistości ze środowiska uniwersyteckiego, ławników kazimierskich. Są w księgozbiorze druki przynależne niegdyś innym domom kanonickim (np. Kurozwęki, Krzemienica), a także innym klasztorom (np. paulini z krakowskiej Skałki, augustianie eremici, karmelici bosi, pijarzy). Proweniencja zbioru wymaga jednak jeszcze szczegółowej analizy.

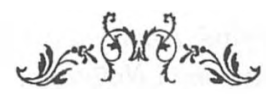

Przypisy:

'Handbuch der Bibliothekswissenschaft. T.3 cz. 1. Wiesbaden 1955 s. 256-257; K. H. Rother: Ein Ausleihregister der Augustiner Chorcherren zu Sagan. Ein Breitag zur Geschichte der Bibliothec. Zenterblatt für Bibliotekswessen 1926 R. 43 s. I-22; E. Amort: Vetus disciplina canonicorum regularium ex documentis magna parte indeditis a temporibus Apostolicis ad saeculum XVII critica et moralite expensa. Venetiae 1747 s. 505-523. 
${ }^{2}$ C. Loniewski: Regula Beatissimi Patris Aurelii Augustini Hipponensis Episcopi, de communi vitae clericorum. Cracoviae 1618 pp. A5-C3 v; S. Ryłko: Regulaśw. Augustyna z klasztonu kanoników regularnych w czeskim Rudniku (pienwsza polowa XIV w.). Kraków 1993.

${ }^{3} \mathrm{ABC}$, rkp [br. sygn.] Compendium Capitulorum Generalium in Congregatione Cracoviensi Canonicorum Regularium Lateranensium celebratarum ab Anno 1628 ad Annum 1751 s. 22.

${ }^{4}$ BSL, rkp [br. sygn.] Dekret wizytacyjny J. Radziwilla z 1596 r. dla klasztoru w Kraśniku k. 11 v; ABC, rkp [br. sygn.] Lumen ad omnimodae iurisdictionis s. 55.

${ }^{5}$ Kodeks dyplomatyczny katedry krakowskiej, 2 nr 499, s. 316; Kodeks dyplomatyczny Malopolski, 4, (M. m. ac. XVII), nr 1238, s. $288 \mathrm{nn}$

"M. Gębarowicz: Psalterz floriański i jego geneza. Wrocław 1965 s. 166.

${ }^{7}$ Księgi radzieckie kazimierskie 1369-1381 i 1385-1402. Wyd. A. Chmiel. Kraków 1932 s. 485 .

' E. Potkowski: Ksiażka rękopiśmienna w kulturze Polski. Warszawa 1984 s. 141; M. Gębarowicz: Psalterz..., op. cit. s. 166.

${ }^{9}$ L. Zalewski: Biblioteka Seminarium Duchownego w Lublinie i biblioteki klasztorne w diecezji podlaskiej. Warszawa 1926 s. 179-199; H. D. Wojtyska: Katalog rękopisów Biblioteki Seminarium Duchownego w Lablinie. Archiwa Biblioteki i Muzea Kościelne T. 281978 nr 5, 6, 10, 13, 14 ; E. Zielinska: Biblioteka klasztonı kanoników regularnych w Kraśniku w drugiej polowie XV wieku. W: Klasztor w kulturze średniowiecznej Polski. Opole-Wroclaw 1995 s. 105-112. - Por. też BPAU Kraków rps 1701-111711; BN Warszawa rps $8037,8039,8043,8044$.

${ }^{10}$ A. Świerk: Średniowieczna biblioteka klasztoru kanoników regularnych św. Augustyna w Żaganiu. Wrocław 1965.

" J. Kiwiliszo: Sredniowieczna biblioteka klasztoru kanoników regularnych w Czerwińsku. Analiza zawartości treściowej. Rocznik BN R. [23-24] 1991 s. 229-254.

${ }^{12} \mathrm{Z}$. Włodek: Inventaire des manuscrits medievaux latins, philosophique et theologiques de la bibliotheque des chanoines reguliers de Cracovie. Medievalia Philos. Pol. [T. 14] 1970 s. $155-188$.

${ }^{13}$ H. Pieńkowska: Sredniowieczna pracownia miniatorska w Krakowie. Rocznik Krakowski T. 321951 s. $45-72$.

${ }^{14} \mathrm{ABC}, \mathrm{Ms} 908,933$.

${ }^{15} \mathrm{BBC}$ [stare sygnatury] 350, 389, 4351, 4609. Ponicważ w BBC trwa opracowywanie zbiorów dalej nie będą cytowane sygnatury, za wyjątkiem oznaczeń $Z$. Włodek. '6ABC Ms 9a

${ }^{17}$ Tamże, Ms 10a. Notka proweniencyjna: lste liber est Andree de Wadowicze alias Stopak presbyterum et prebendarium capelle Sancti Nicolai in castro Teschnensi.

${ }_{18}$ Tamże, Ms 14a

19 Tamże, Ms 489

${ }^{20}$ Tamże, Ms 906

${ }^{21}$ Tamże, Ms 1453; Ms [b. sygn.].- Por. B. Ulanowski: Mikolaj z Błonia, kanonista polski z pierwszej polowy XV wieku. Rozprawy: AU. Wydzial Historyczno-Filozoficzny [R.] 23 [1888] s. 1-60; M. T. Zahajkiewicz: Tractatus sacerdotalis Mikolaja z Blonia. Lublin 1979. 
${ }^{22}$ ABC Ms 907.- Por. S. Bylina: Wplywy Konrada Waldhausena na ziemiach polskich w drugiej polowie XIV i pierwszej połowie XV wieku. Wrocław-Warszawa-Kraków. 1966.

${ }^{23}$ Tamże, Ms 9a.

${ }^{24}$ M. Rechowicz: Poczqtki i rozwój kultury scholastycznej (do końca XIV wieku). W: Dzieje teologii katolickiej w Polsce T. I Sredniowiecze. Lublin 1974, s. 19-91.

${ }^{25}$ J. Wolny: Kaznodziejstwo. W: Dzieje... op. cit., s. 275-308.

${ }^{26}$ Por. A. Świerk: Sredniowieczna... op. cit.

${ }^{27}$ APMK, rkp K 888 [s. 266-268.] [spis zakonników XV w. zawiera kaznodziejów polskich i niemieckich].

${ }^{2 \pi}$ BZN im. Ossolińskich: Katalog Biblioteki Klasztoru Augustianów (Bożego Ciala) w Krakowie na Kazimierzu, 1741 r. (stanowi część rękopisu rajcy kazimierskiego Marcina Golińskiego).- Por. Z. Staniszewski: Inwentarze biblioteczne wieku XVII i XVIII w rękopisach Ossolineum. Ze skarbca kultury 1955 z. 1 (7), s. 202-203.

${ }^{29} \mathrm{ABC}, \mathrm{II}-\mathrm{A}-7$ Cathalogus librorum bibliothecae SS. Corporis Christi Canonicorum Lateranensium Casimiriae ad Cracoviam consriptus $A D 1811$.

${ }^{30}$ Tamże, Additur Collectio librorum manuscriptorum caractere gothico, qui extra armaria supranumerata extant in eadem Bibliotheca, s. 220-221.- [właściwie jest 53 rękopisy, bo ostatni zapis to „Canapiusa Thesaurus pol-lat-grec., Cracovia 4* t. 3 typ. excud.”].

31 J. Pachoński: Drukarze, księgarze i bibliofile krakowscy 1750-1815. Kraków 1962, s. 228.

${ }^{32}$ Tamże, s. 229.- Por. APMK, nr 234 1/2 „K” Akta poaust. cyrkulu krak. tyczqce się spisu inwentarzy bibliotek po klasztorach krak.; R. Kaczmarczyk: Rewizja bibliotek klasztorów krakowskich w r. 1810. Przegląd Biblioteczny 1909 T. 2, s. 182; L. Lętowski: Katalog biskupów, pralatów i kanoników krakowskich. T. 3. Kraków 1852, s. 267.

${ }^{33}$ BPAU Kraków, rkp 401.

${ }^{34}$ Por. A. Wetulani: Dekret Gracjana i pienwsi dekretyści w świetle nowego źródla. Wrocław-Kraków 1955.

${ }^{35}$ I. Pietrzkiewicz: Prohibity w Bibliotece Bożego Ciala, kanoników regularnych w Krakowie (artykuł złożony do druku Prace Bibliotekoznawcze).

${ }^{36}$ J. Pachoński: Drukarze..., op. cit., s. 243.

${ }^{37}$ J. A. Kosiński: Biblioteka funadacyjna Józefa Maksymiliana Ossolińskiego. Wrocław 1971 s. 73.- S. B. Linde: Slownik języka polskiego. T. 1. Lwów 1854, s. 25.

${ }^{38}$ Katalog inkunabulów Biblioteki Zakladu im. Ossolińskich we Wroclawiu. Oprac. A. Kawecka-Gryczowa. Wrocław 1956, s.76-77. 